\title{
THE TRINITARIAN REFLECTION ON THE PRIMACY OF GOD THE FATHER
}

\author{
Samuel Andri
}

\begin{abstract}
The article reconsiders the Eastern Christian concept of the Primacy or the Monarchy of God the Father, which has often been deemed as irrelevant and destructive in many modern Trinitarian reflections. For some modern Trinitarian theologians, the hierarchical notion that comes from the idea of the Primacy of God the Father is in complete opposition with the concept of perichoresis, which subvert any forms of hierarchy. Using St. Gregory of Nazianzus' Theological Oration, the author, however, maintains that the Primacy of God the Father should be preserved, precisely because it provides the foundation for the divine perichoresis to be consistent with Christian monotheistic affirmation.
\end{abstract}

Keywords: Trinity, Perichoresis, Monarchy, Primacy, Hierarchy

\begin{abstract}
Abstrak
Artikel ini mempertimbangkan kembali konsep Kristen Timur tentang Keutamaan atau Monarki Allah Bapa, yang sering dianggap tidak relevan dan merusak dalam banyak refleksi Trinitarian modern. Bagi beberapa teolog Trinitarian modern, gagasan hierarkis yang berasal dari gagasan Keutamaan Tuhan Bapa sepenuhnya bertentangan dengan konsep perichoresis, yang menumbangkan segala bentuk hierarki. Dengan menggunakan St. Gregorius dari Orasi Teologis Nazianzus, penulis, bagaimanapun, menyatakan bahwa Keutamaan Tuhan Bapa harus dilestarikan, justru karena itu memberikan landasan bagi perichoresis ilahi agar konsisten dengan penegasan monoteistik Kristen.
\end{abstract}

Kata kunci: Trinity, Perichoresis, Monarki, Primacy, Hirarki

\section{INTRODUCTION}

The rise of the Trinitarian theology in the latter part of the twen-tieth century, which many people be-lieve to be initiated by Karl Barth ${ }^{1}$, helps us to consider the mystery of the Father - Son - Spirit in a way that enables us to speak of the Christian God not in a pure speculative fashion, but in relation to God's work in his-tory through the incarnation of Christ. This foundational assertion in the modern development of the Trinitarian theology is descriptively summed up by Karl Rahner, when he writes, "The "economic" Trinity is the "immanent" Trinity and the "immanent" Trinity is the "economic" Tri-

${ }^{1}$ Roger E. Olson and Christopher A. Hall, The Trinity in Guides to Theology series (Grand Rapids: Wm. B. Eerdmans Publishing Co., 2002), 95-96. nity. ${ }^{2}$ For Rahner, God in the "immanence" of Godself is identical to the God who has been revealed in the salvation history.

Since then, many theological works have been composed based on this assertion, as the Trinity is no longer deemed to be purely specu-lative or a useless teaching in the Christian theology, as many people, including Schleiermacher, thought. ${ }^{3}$ The Trinity becomes the starting point for any other Christian doctrine and it also becomes an archetype for our practical Christian living. Many contemporary Trinitarian reflections have focused on divine unity by retrieving the concept of perichoresis and using that concept to

${ }^{2}$ Karl Rahner, The Trinity, trans. Joseph Donceel (New York: Cross-road, 1997), 22.

${ }^{3}$ Catherine Mowry LaCugna, God for Us: The Trinity \& Christian Life (New York: HarperCollins Publishers, 1993), 144. 
embrace the Christian notions of hospitality, interdependency, openness, and plura-lism. ${ }^{4}$

While this communal model of Trinitarian reflections has ac-complished many valuable practical instructions for the life of the Church, I think it overlooks some problems in its reflections. For example, it is not always able to avoid the impression of Tritheism. Moreover, since the Christian tradition must also fully express its monotheistic affirmation, we need to also have Trinitarian reflections, which express mono-theistic feature in a more noticeable way. In other words, we must be clear in our reflections that the Trinity is the One God. For that reason, this paper attempts to find the possibilities to fill the theological gap in the contemporary Trinitarian reflections by utilizing the prominent eastern concept of the primacy or monarchy of God the Father as the means to make sense of the Divine unity, which then enables us to construct a practical Trinitarian reflection, which show the monotheistic feature of our tradition in a more perceptible way. I am aware, however, that in this reflection, we need to also consider the moral and cultural baggage of today's world, when the notion of primacy and/or hierarchy has been used negatively, even by the Church, to mistreat others. $^{5}$ Thus, this reflection requires greater sensitivity towards these common negative perceptions, while at the same time we try to retrieve the important aspect of our Christian tradition.

\section{THE LIMITATIONS OF PERI- CHORESIS IN THE SOCIAL TRINITARIAN REFLECTIONS}

It is often asserted that Eastern Christianity took the three persons as the starting point and then asked about the

${ }^{4}$ LaCugna, God for Us, 400-406.

${ }^{5}$ Kevin Giles, The Trinity \& Subordinationism: The Doctrine of God \& the Contemporary Gender Debate (Downers Grove: IVP Press, 2002).

${ }^{6}$ LaCugna, God for Us, 6. unity, while the Western Christianity began with the oneness of God and then tried to explain the three persons. ${ }^{6}$ For the proponents of social Trinitarian reflections, the West's flow of thoughts, which begin with the oneness of God and then struggle to explain the three persons, becomes the primary reason why the doctrine of Trinity has been deemed as irrelevant because if one has already begun with prior conceptions of God, then the latter account, namely the three persons, will only become "a secondary bit of information to be reconciled with a prior, less proble-matic understanding of God."7 Thus, for many social Trinitarian theo-logians, in order to resolve the issue, one needs, like in the East generally speaking, to begin with the three persons of God and then try to make sense of the Christian affirmation that God is one. Here, the divine perichoresis, "the mutual indwelling", is often used in social Trinitarian reflections to explain why the three persons are one. For example, Jürgen Moltmann argues, "The doctrine of the perichoresis links together in a brilliant way the threeness and the unity, without reducing the threeness to the unity, or dissolving the unity in the threeness."

On one hand, the concept of perichoresis is surely attractive as it displays the Christian God as inherently and perfectly interrelated in loving communion, which then has practical implications on how we should live in the light of the Trinity. Yet, on the other hand, it could also be problematic for two reasons. First, it falls short in displaying the monotheistic affirmation of our Christian tradition. This is due to what Karen Kilby calls as the 'problems of projection'. Second, as Kathryn Tanner noticed, it falls short due to the fact that the concept could also be used reversely in order to suggest

\footnotetext{
${ }^{7}$ Karen Kilby, "Perichoresis and Projection: Problems with Social Doctrines of the Trinity," New Blackfriars 81 (2000), 434

${ }^{8}$ Jürgen Moltmann, The Trinity and the Kingdom of God (London: SCM, 1981), 175.
} 
negative reflections, thus could be equally problematic as monotheism. ${ }^{9}$

In regards to the problems of projection, Kilby starts her argument by asserting that for social theorists, God is more appropriately displayed as three persons, rather than as one. However, since they do not want to be Tritheists, they must say that the three divine persons, even if they are separate centers of will or hypostasis, make only one God. ${ }^{10}$ But, since there is no clear explanation in the scripture, then it must be beyond our human experience, especially since in human experience, three persons mean simply three people. Kilby then argues, "This whatever it is, this thing which is beyond our experience which binds the three into one, however, is given a label—it is called the divine perichoresis." 11 The perichoresis, then, is used to name something that we do not understand, namely how the three binds into one. But, still, the issue remains, due to the fact that we still do not know what does it mean to say that the three persons of the Trinity interpenetrate one another in their shared life and yet, still remain one God in three distinct persons. ${ }^{12}$ The social theorists would then take the language from our human experience in order to better describe this concept. While, it is true that any language used to talk about God is drawn from our human experiences, yet the problem for perichoresis-based Trinitarian reflections, at least for Kilby, is that "... what is at its heart a suggestion to overcome difficulty is presented as a key source of inspi-ration and insights." ${ }^{13}$ In other words, the concept of perichoresis is not only filled with the notions from our human experience of relation-ships, related-ness,

${ }^{9}$ Kathryn Tanner, "Social Trini-tarianism and its Critics," in Rethinking Trinitarian Theology, eds. Robert J. Woźniak and Giulio Maspero (London: T\&T Clark, 2012), 374-375.

${ }^{10}$ Kilby, "Perichoresis and Projec-tion", 440.

${ }^{11}$ Kilby, "Perichoresis and Projec-tion", 440. and community in order to overcome the difficulty, but it is also then presented as the theo-logical resource for the wider world in its reflections and thus, as Karen Kilby rightly argues, “... what is projectted onto God is immediately reflected back onto the world, and this reverse projection is said to be what is in fact important about the doctrine." 14 Thus, we seek what we already desire and then claim to have found it in the doctrine itself.

Due to this problem of reverse projection, it is not surprising that social Trinitarian reflections often fall short in giving accurate explanations and/or reflections, which hold the fundamental aspects of Christian tradition, both the three-ness and oneness of God as witnessed in the scripture. This is due to the fact that nothing in our human experiences could adequately demonstrate the inner life of God. Yet, the reverse projection, which is being done by many social theorists, would naturally give an inaccurate impression of God's inner life since, again, in our human experiences, three persons simply mean three people.

Nevertheless, for Trinitarian reflections to work, it must hold these two aspects of three-ness and oneness of God, at least, in an equal emphasis. Although, I might argue that in the thoughts of the patristic fathers, the main focus is to find the way to reconcile how the three persons are one, and thus, it logically implies that we should put more emphasis in the oneness of God. But how could these two aspects of Christian tradition be adequately displayed, when social Trinitarian reflections base their arguments on their general repugnance towards monotheism, which according to them, supports

${ }^{12}$ Oliver D. Crisp, "Problems with Perichoresis," in Tyndale Bulletin 56.1 (2005), 140. Accessed online on April 20 2018 at http:/tyndalehouse.com/tynbul/library/TynBull_200 5_56_1_07_Crisp_PerichoersisProblems.pdf

${ }^{13}$ Kilby, "Perichoresis and Projec-tion", 441.

442. 
authoritarianism $^{15}$, exclusive power $^{16}$, monolithic iden-tities, and negative hierarchical re-lations centered on male? ${ }^{17} \mathrm{I}$ think Kathryn Tanner, -after showing some possibilities of the abuse of this idea-, rightly argues, "Clearly, then, Trinitarianism can be every bit as socially and politically dangerous as mono-theism. Everything depends on how that Trinitarianism (or monotheism) is understood and applied. ... What these theologians are trying to do, indeed, is systematically modify as many of the politically problematic aspects of classical Trinitarianism as they can."18 Accordingly, Tanner also argues that monotheism could also suggest positive reflections. For example, the monotheistic proponent could propose "that no one shares in the divinity of God and therefore no one can stand in as God's representative: 'no lord but God'."19

Therefore, knowing the limitations of current social Trinitarian reflections, we could, perhaps find a better model, either to substitute it or to complement the current theological reflections. My focus in the next part of this paper, is to find the possibilities for supplementing the current social Trinitarian reflections, which I believe put too much emphasis on the three 'persons' of God by diminishing, though indirectly and unintentionally, the monotheistic affirmation of our Christian tradition.

\section{THE DIVINE CAUSALITY AND THE PRIMACY OF GOD THE FATHER}

One of the ways for the Church fathers to hold the claim that the Christian God, although being three persons is one, is by presenting the primacy of God the Father. But not many modern theologians would agree with the Church Fathers.

\footnotetext{
${ }^{15}$ Moltmann, The Trinity and the Kingdom of God , 192-199.

${ }^{16}$ Leonardo Boff, Trinity and Society (New York: Orbis Books, 1988), 22-25

${ }^{17}$ Lacugna, God for Us, 268-269.

${ }^{18}$ Tanner, "Social Trinitarianism and its Critics," 375.
}

Wolfhart Pannenberg, for example, argues that the primacy of the Father threatens the equality of the three persons and fails to distinguish the Father from the divine substance. $^{20}$ Moreover, accor-ding to LaCugna, "the idea of peri-choresis emerged as a substitute for the earlier patristic notion that the unity of God belonged to the person of the Father." 21 In other words, if we follow LaCugna's thought, there was a time when the primacy of the Father was the answer for the unity of God, which was then substituted by the concept of the divine perichoresis. One may doubt LaCugna, when she argues that perichoresis is the substitution for the primacy of God the Father, nevertheless this claim reveals how the current social Trinitarian reflections often considers the concept of the primacy of the Father and divine perichoresis as being opposed to each other.

From the works of St. Gregory of Nazianzus, however, we know that the primacy of God the Father does not necessarily oppose the ontological equality of the three persons. In Gregory's writings, one can not only discover his strong affirmation to the primacy or monarchy of God the Father, but we can also find the concept of perichoresis, though not explicitly containing the word perichoresis or any of its derivatives. For example, one of the most frequently cited is Oration 31.14:

We have one God because there is a single Godhead. Though there are three objects of belief, they derive from the single whole and have reference to it. They do not have degrees of being God or degrees of priority over against one another. They are not sundered in will or

\footnotetext{
${ }^{19}$ Tanner, "Social Trinitarianism and its Critics," 371.

${ }^{20}$ Wolfhart Pannenberg, Systematic

Theology, trans. Geoffrey W. Bromiley (Grand Rapids: Eerdmans Publishing, 1991) 279-280.

${ }^{21}$ Lacugna, God for Us, 270.
} 
divided in power. You cannot find there any of the properties inherent in things divisible. To express it succinctly, the Godhead exists undivided in beings divided. It is as if there were a single intermingling of light, which existed in three mutually connected Suns. When we look at the Godhead, the primal cause, the sole sovereignty, we have a mental picture of the single whole, certainly. But when we look at the three in whom the Godhead exists, and at those who derive their timeless and equally glorious being from the primal cause, we have three objects of worship." 22

I am aware that Gregory's position in regards to these two concepts is not without confusion. Many scholars have been debating about what does Gregory truly teach and/or believe in regards to the Divine Causality. The puzzlement is caused by the fact that there seems to be two different concepts of the primacy of the Father in Gregory's works. In some part of his works, Gregory seems to maintain that the Father, the Son, and the Spirit, all derive from a common First Cause, or the Divinity $^{23}$, which then implies that the Divinity is the primal cause of the three persons of the Trinity and becomes the ground of the divine unity. ${ }^{24}$ However, in some other parts, Gregory seems to argue that the Father is the First Cause, and he even argues that the Son and the Spirit are

${ }^{22}$ Oration 31.14. Gregory of Nazianzus, Faith Gives Fullness to Reasoning: The Five Theological Orations of Gregory Nazianzen (intro. And commentary Frederick W. Norris; trans, Lionel Wickham and Frederick Williams (Leiden: Brill, 1991), 286.

${ }^{23}$ Gregory, Oration 31.14

${ }^{24}$ Christopher A. Beeley, "Divine Causality and the Monarchy of God the Father in Gregory of Nazianzus," in Harvard Theological Review 100.2 (2007), 200.

${ }^{25}$ Gregory, Oration 29.3, 15. "less" than the Father in terms of causality, though not in terms of nature. ${ }^{25}$

This confusion has led to a scholarly debate on whether the Father is the cause of the Son, making the Son as ontologically inferior, or the Father does not cause the Son, thus they are purely equal. For E. P. Meijering, Gregory's double claim that the Father causes the Son and that they are ontologically equal are untenable since Meijering assumes that 'causal subordinationism' and 'causeless equality' are the only two options. ${ }^{26}$ Some scholars, like R.P.C. Hanson and Lewis Ayres, conclude that the divine essence is the Primal Cause, from which all three persons derive. ${ }^{27}$ Others, like John Egan, conclude that Gregory's doctrine of the causality of the Father is on the whole "philosophically arbitrary." 28 Still other scholars, like John McGuckin and Fr. John Behr, argue that ultimately, Gregory identifies God the Father as the source and cause of the Son and the Spirit. ${ }^{29}$

Considering these different positions, Christopher A. Beeley argues that "Much of the difficulty among recent studies appears to stem from an almost exclusive reliance on the Theological Orations at the expense of other, equally important texts." Beeley argues that since most Theological Orations are defensive in character, which principally are a series of responses to theological objections from his opponents (Eunomians and Pneumatomachians). For Beeley, "we must therefore look to other texts that bring out more directly the doctrinal commitments

${ }^{26}$ Beeley, "Divine Causality and the Monarchy of God the Father in Gregory of Nazianzus," 202.

${ }^{27}$ Lewis Ayres, Nicaea and Its Legacy: An Approach to Fourth-Century Trinitarian Theology (New York: Oxford University Press, 2004), 244245.

${ }^{28}$ John Egan, "Primal Cause and Trinitarian Perichoresis in Gregory Nazianzen's Oration 31.14" in Studia Patristica 27 (1993), 21-28.

${ }^{29}$ Beeley, "Divine Causality and the Monarchy of God the Father in Gregory of Nazianzus," 204. 
that Gregory is defending in the Theological Orations." ${ }^{30} \mathrm{He}$ then refers to Gregory's Oration 25.15-18, which he considers as "the most straightforward, and probably the most significant," in regards to Gregory's Trinitarian doctrine. Gregory dedicates Oration 25 for Maximus the Cynic, as Maximus is about to return home to Alexandria. ${ }^{31}$ I will quote the opening statement in full. Gregory tells Maximus, "Define our piety, by teaching the knowledge of:

One God, unbegotten, the Father; and One begotten Lord, his Son, referred to as "God" ( $\theta \varepsilon$ ó $\varsigma$ ) when he is mentioned separately, but "Lord" when he is named together with the Father-the first on account of the [divine] nature, the second on account of the monarchy; and

One Holy Spirit, who proceeds

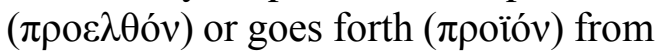
the Father, "God" ( $\theta \varepsilon$ óv) to those who understand properly things proposed to themcombated by the impious but understood by those who are above them, and even professed by those who are more spiritual.

[Teach] also that we must not make the Father subject to [another] source (v $\alpha \rho \chi \eta \dot{v})$, lest we posit a "first of the First," and thus overturn the [divine] Existence. Nor should we say that the Son or the Holy Spirit is without source

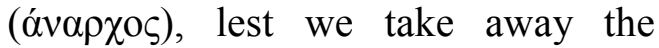
Father's special characteristic ( $\tau$ o 'íiov). For they are not without source - and yet in a sense they are without source, which is a paradox.

\footnotetext{
${ }^{30}$ Beeley, "Divine Causality and the Monarchy of God the Father in Gregory of Nazianzus," 204

${ }^{31}$ Beeley, "Divine Causality and the Monarchy of God the Father in Gregory of Nazianzus," 205.

${ }^{32}$ Gregory, Oration 25. 15
}

They are not without source with respect to their cause $(\tau \omega \alpha \iota \tau i ́ \omega)$, for

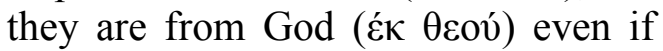
they are not subsequent to him in time ( $\left.\mu \varepsilon \tau^{\prime} \alpha v \tau o ́ v\right)$, just as light comes from the sun. But they are without source with respect to time, since they are not subject to time." 32

For Gregory, the primacy of God the Father is the fundamental unifying aspect of the Trinity and also the root of Trinitarian distinctions, both from the eternal perspective. On one hand, the primacy of the Father is the fundamental unifying aspect of the Trinity because, for Gregory, the Father's superiority to the Son [and the Spirit] is due to 'him' being the eternal source of their Divinity, thus all three persons are ómoov́otos and thus, are one God. There is one God because the Son and the Spirit 'converge' on their source, the Father, in perfect union of divine nature, will, and action. ${ }^{33}$ Therefore, when the scripture talks about God the Father as greater than the Son or the Spirit, Gregory interprets it as a direct, theological claim about the life of God. ${ }^{34}$ The unity of the Trinity, in that sense, is the eternal result of the Father's divine generation.

On the other hand, the primacy of the Father is the root for Trinitarian distinctions because the Father's eternal and divine generation preserve the three persons in their unique status, namely that the Father would always be the Unbegotten or the Source without source, the Son would always be the eternal begotten from the Father or the Source from the Source, and the Spirit would always be eternally proceeded from the Father, the Perfector. Therefore, what makes the three persons distinct from each other is the unchangeable

\footnotetext{
${ }^{33}$ Gregory, Oration 29.2

${ }^{34}$ Beeley, "Divine Causality and the Monarchy of God the Father in Gregory of Nazianzus," 208.
} 
status, which derives from the eternal result of the Father's divine generation.

For that reason, Gregory maintains that God the Father is the Divine eternal Cause of the Son and the Spirit; yet, the three distinct persons are ontologically equal because eternally, the Father fully conveys 'his' Divinity to the Son and the Spirit as 'he' generates them. That being said, as Beeley notes, "there is no sense of causality and ordered hierarchy in the Trinity except the one by which the Father produces the Son and the Spirit as full partakers in his Divinity and thus ontological equals." 35 Thus, the perichoresis in the Trinity is possible only because there is a Divine causality in an eternally prior sense. ${ }^{36}$ Gregory's explanation, I believe, is more faithful to both proclamations of the Scripture in regards to the three-ness and the oneness of God.

\section{THE POSSIBILITY FOR A HOLISTIC TRINITARIAN RE-FLECTION}

Considering Gregory's ac-counts on the primacy of the Father, I think it is important for our current social Trinitarian reflections to consider these three main things: a) the primacy of the Father, in the eternal sense, does not contradict the ontological equality of the three persons. In fact it is needed in order to defend both the Trinitarian distinc-tions and unity, b) the primacy of the Father does not mean that there is a hierarchy of authority in the inner life of the Trinity as if the three persons have three distinct wills, which then needs to be organized or ordered by the Father, c) the primacy of God the Father is required to make sense of how the three persons are one God, because eternally, 'he' fully and perfectly conveys 'his' Divinity towards the

\footnotetext{
${ }^{35}$ Beeley, "Divine Causality and the Monarchy of God the Father in Gregory of Nazianzus," 213.

${ }^{36}$ Beeley, "Divine Causality and the Monarchy of God the Father in Gregory of Nazianzus," 213.
}

Son and the Spirit and they 'converge' in the perfect union of will and nature. This, for John Zizioulas, becomes the reason why we could speak of God as love. ${ }^{37}$

That being said, I would like to briefly suggest a possibility in using Gregory's concept of the primacy of the Father in our Trinitarian reflec-tions. From the Trinity, we could see that although there is an eternal rank, -in regards to the eternal status of the Father as the Unbegotten Cause, the Son as the Begotten, and the Spirit as the one Proceeded from the Father, yet there is no hierarchy of authority in the life of the Trinity. There is no hierarchy of authority because eternally, the Father fully and perfec-tly conveys 'his' Divinity to the Son and the Spirit, as a result, the three persons are perfectly One in nature, will, and action.

The Trinity shows us not only what it means to live in perfect loving, interrelated, interdependent commu-nity, but it also shows us that just like God the Father, though eternally Unbegotten, thus the Source of the Son and the Spirit, yet the Father is perfectly willing to fully convey his 'Divinity', thus nature, will, and authority, to the Son and the Spirit. In other words, the so-called higher 'hierarchy of rank' of the Father is not becoming the reason for the Father to 'rule over', but conversely, it is becoming the reason for the Father to completely obliterate our understand-ing of the hierarchy in order to have the divine perichoretic relationship with the Son and the Spirit.

This kind of reflection would naturally demonstrate both the three-ness as well as the oneness aspects of God, which are fundamental in our Christian tradition. Moreover, it would also reject any abuse of power and authority, since the primacy of the Father eternally rejects the notion of

\footnotetext{
${ }^{37}$ John D. Zizioulas, Being as Communion: Studies in Personhood and the Church (New York: St. Vladimir's Seminary Press, 1985), 46.
} 
hierarchy of power and authority in order to eternally demonstrate the perichoretic kind of relationship in the life of the Trinity.

\section{BIBLIOGRAPHY}

Ayres, Lewis. Nicaea and Its Legacy:

An Approach to Fourth-Century

Trinitarian Theology. New York:

Oxford University Press, 2004.

Beeley, Christopher A. "Divine

Causality and the Monarchy of God the Father in Gregory of Nazianzus." in Harvard Theological Review 100.2 (2007). 199- 214.

Boff, Leonardo. Trinity and Society. New York: Orbis Books, 1988.

Crisps, Oliver D. "Problems with Perichoresis." in Tyndale Bulletin 56.1 (2005). Accessed online on April $20^{\text {th }} \quad 2018 \quad$ at http:/tyndalehouse.com/tynbul/libra ry/TynBull_2005_56_1_07_Crisp_ PerichoersisProblems.pdf

Egan, John. "Primal Cause and Trinitarian Perichoresis in Gregory Nazianzen's Oration 31.14". in Studia Patristica 27 (1993), 21-28.

Giles, Kevin. The Trinity \&

Subordinationism: The Doctrine of God \& the Contemporary Gender Debate. Downers Grove: IVP Press, 2002.

Gregory of Nazianzus, Faith Gives

Fullness to Reasoning: The Five Theological Orations of Gregory Nazianzen. Introduction And commentary Frederick W.

Norris; trans, Lionel Wickham and Frederick Williams. Leiden: Brill, 1991.

Kilby, Karen. "Perichoresis and

Projection: Problems with Social Doctrines of the Trinity." New Blackfriars 81 (2000).
LaCugna, Catherine Mowry. God for Us: The Trinity \& Christian Life. New York: HarperCollins Publishers, 1993.

Moltmann, Jürgen. The Trinity and the Kingdom of God. London: SCM, 1981.

Olson, Roger E. and Christopher A. Hall. The Trinity in Guides to Theology series. Grand Rapids: Wm. B. Eerdmans Publishing Co., 2002.

Pannenberg, Wolfhart. Systematic Theology. trans. Geoffrey W. Bromiley. Grand Rapids: Eerdmans Publishing, 1991.

Rahner, Karl. The Trinity. trans. Joseph Donceel. New York: Crossroad, 1997.

Tanner, Kathryn. "Social Trinitarianism and its Critics," in Rethinking Trinitarian Theology. eds. Robert J. Woźniak and Giulio Maspero. London: T\&T Clark, 2012.

Zizioulas, John D. Being as Communion: Studies in Personhood and the Church. New York: St. Vladimir's Seminary Press, 1985.

\section{BIODATA PENULIS}

Samuel Andri saat ini sedang menyelesaikan studi M.A.T.S di Vancouver School of Theology. 